\title{
Aboveground Woody Biomass, Carbon Stocks Potential in Selected Tropical Forest Patches of Tripura, Northeast India
}

\author{
Koushik Majumdar*, Bal Krishan Choudhary, Badal Kumar Datta \\ Plant Taxonomy and Biodiversity Laboratory, Department of Botany, Tripura University, Suryamaninagar, India \\ Email: *majumdark80@gmail.com
}

How to cite this paper: Majumdar, K., Choudhary, B.K. and Datta, B.K. (2016) Aboveground Woody Biomass, Carbon Stocks Potential in Selected Tropical Forest Patches of Tripura, Northeast India. Open Journai of Ecology, 6, 598-612.

http://dx.doi.org/10.4236/oje.2016.610057

Received: May 8, 2016

Accepted: September 20, 2016

Published: September 23, 2016

Copyright $\odot 2016$ by authors and Scientific Research Publishing Inc. This work is licensed under the Creative Commons Attribution International License (CC BY 4.0)

http://creativecommons.org/licenses/by/4.0/

\begin{abstract}
To estimate woody plant biomass stocks in different patches of forest ecosystems, total $20,500 \times 10 \mathrm{~m}(0.5 \mathrm{ha})$ sized line transects were laid in a protected area of Tripura, Northeast India. Overall, 9160 individuals were measured at $\geq 10 \mathrm{~cm}$ diameter at breast height (dbh) in 10 ha sampled area. Estimation of biomass suggested that highest coefficient for allometric relationships between density and biomass in 10 dbh classes was observed in bamboo brakes $\left(R^{2}=0.90\right)$ than lowest for semi evergreen patch $\left(\mathrm{R}^{2}=0.48\right)$. The stock of carbon $(\mathrm{C})$ was differ significantly along the forest patches $(\mathrm{F}=7.01, \mathrm{df}=3.19 ; \mathrm{p}<0.01)$. Most of biomass stock $(69.38 \%)$ was accumulated in lower dbh class $(<30 \mathrm{~cm})$ and only $23 \%$ of biomass was estimated at higher dbh classes $(>70 \mathrm{~cm})$. Range of biomass stock $\left(37.85-85.58 \mathrm{Mg} \mathrm{ha}^{-1}\right.$ ) was low, compared to other tropical forest ecosystems in India, which implies that the proper management is required to monitor regional ecosystem $\mathrm{C}$ pool.
\end{abstract}

\section{Keywords}

Woody Biomass, Potential Carbon Storage, Tropical Forest Patches, Tripura

\section{Introduction}

World wide tropical forests are accounts about $40 \%$ of the total carbon (C) storage as terrestrial biomass [1] and, thus playing a fundamental role in the global $\mathrm{C}$ cycle [2]. Spatial distribution of tropical forest biomass is influenced by a range of climatic, edaphic and anthropogenic factors [2]. Out of total C stored in ecosystem ca.90\% loses are due to loss of living biomass, an indicator of ecosystem services [1] [3]. In fact, $\mathrm{C}$ emissions from deforestation and forest degradation are one of the most important chal- 
lenges for global climate change and mitigation of greenhouse gasses [4]. Quantification of biomass, $\mathrm{C}$ and its distributions, even in local forest ecosystems comprises the significant parts of global C budget; and, thus important component of the basis for predicting future climate change [4]. To better understand the climate change and its impacts, information on fragmented forest patch, their biomass and $\mathrm{C}$ storage is still needed at regional and local scales [4] [5]. Given the high rate of deforestation in tropical forest and the limited extent of old growth tropical forests [4] [6] [7], determination of above-ground biomass (AGB) and C stocks in the remaining forest patches are the important concerns and priorities for most of the ecologist.

According to Ramachandra \& Shwetamala (2012) [8], forest biomass contributing $74 \%$ of total C in India; and annually, $7.35 \%$ of total C emissions get stored in either forest biomass or in soil. During 1995-2005, C stocks in forest vegetation have increased from 6245 - $6662 \mathrm{mt}$, registering an annual increment of $38 \mathrm{mt}$ of $\mathrm{C}$ or $138 \mathrm{mt}$ of equivalent $\mathrm{CO}_{2}$; which recorded that forests have neutralized about $11.25 \%$ of total $\mathrm{CO}_{2}$ equivalent greenhouse gas emission [9]. In Northeast India, numerous experiments have quantified forest biomass structure and $\mathrm{C}$ stock in different forest ecosystems [10]-[13]. However, it is widely recognized that Northeast India represents several virgin, natural, semi-natural and modified ecosystems due to greater variation in physiographic, climatic, edaphic and anthropogenic factors [14]. Tripura is the second smallest state of Northeast India, the estimation of biomass and C stock for Tripura was investigated [15] [16]. In 2010, Forest survey of India (FSI) has completed estimation of forest carbon stock and change between two time period viz1994 and 2004 as part of Second National Communication [17]. Forest fragmentation followed by high anthropogenic pressure typically affected the forest characteristics and thereby reduced Caccumulation rate [18] [19]. Since the time of earlier studies, land degradation and habitat modification have resulted serious loss of biomass stocked in this region. Tree composition and structure are the important predictive variable when estimating AGB [20]. Since forest structure and biomass are known to vary along different environmental gradients, including forest types and communities [20]; and, even along the successional gradients [21]. We hypothesized that, stand density should decrease from early to late successional stages; biomass and $\mathrm{C}$ storage should increase from early to late stages. We also hypothesized that understanding tree age class variables are also crucial to know the differences in biomass and C stock across a successional gradient. Despite these results, $\mathrm{C}$ stock has yet to be studied or quantified form wide landscape levels and to be incorporated in global $\mathrm{C}$ estimation, especially across relatively less studied tropical moist deciduous forest ecosystem. Hence, there was a need to estimate biomass and $\mathrm{C}$ storage for better understanding of local forest ecosystem dynamics. Thus, overall objective of this study was set to 1) quantify first structure of woody species along different tropical moist forest patches, to 2) estimate biomass and Cstocks in different forest patches and to 3 ) observe how above-ground biomass and density vary from semi evergreen forest to moist deciduous vegetation patches along different age classes. 


\section{Material and Methods}

\subsection{Study Area}

We conducted our field studies in Tripura, which is the second smallest state of Northeast India with total $10,491 \mathrm{~km}^{2}$ geographical area. This sanctuary covers total 194.704 $\mathrm{km}^{2}$ geographical area located between $23^{\circ} 05^{\prime} \mathrm{N}-23^{\circ} 25^{\prime} \mathrm{N}$, and $91^{\circ} 20^{\prime} \mathrm{E}-91^{\circ} 35^{\prime} \mathrm{E}$ (Figure 1), which was notified in November 1988, with total 27 revenue Mouza of Belonia, Udaipur and Sonamura Civil sub-division of South Tripura District. As per the Champion and Seth (1968) [22] classification system forest types of the sanctuary mainly consists of: 1) Cachar Tropical Semi Evergreen Forest 2) East Himayan lower Bhabhar

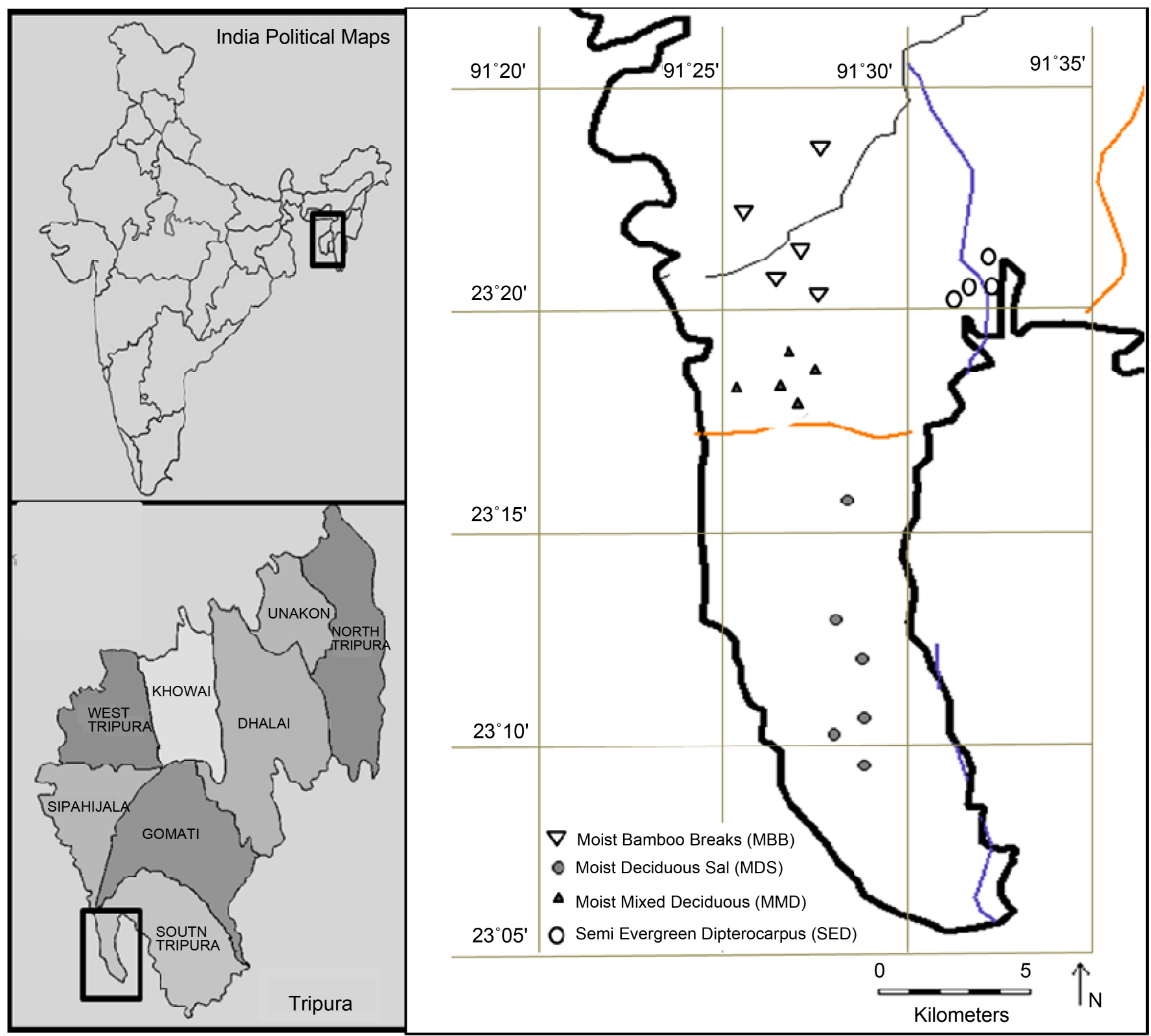

Figure 1. Location of the study area and sampling points in TWS. 
Moist Deciduous Sal Forest, 3) Moist Mixed Deciduous Forest, 4) Moist Bamboo Brakes and 5) Savanah Wood Land [23]. The elevation of the study sites ranges between $17 \mathrm{~m}$ to $83 \mathrm{~m}$ above mean sea level. The climate of this area is generally moist and humid. The minimum and maximum temperatures in summer are $21^{\circ} \mathrm{C}$ and $38^{\circ} \mathrm{C}$. In winter it ranges between $4^{\circ} \mathrm{C}$ and $33^{\circ} \mathrm{C}$. Humidity is generally high throughout the year. In the summer season the relative humidity differs between $50 \%-74 \%$ whereas in the rainy season it is over $85 \%$. The mean wind speed is $7.1 \mathrm{~km} / \mathrm{hr}$, with maximum of 13.1 $\mathrm{km} / \mathrm{h}$ in May and minimum of $3 \mathrm{~km} / \mathrm{h}$ in December. The mean annual rainfall varies between 192 - $285 \mathrm{~cm}$ and increased from Southwest to Northeast. The soil type of the study area is mainly red loam and sandy loam soils.

\subsection{Field Data Collection}

Vegetation inventories data were collected during 2010 to 2011 by 20 line transects. Line transects were placed randomly in different forest patches in Trishna Wildlife Sanctuary. The successional gradients were identified visually following the characteristics drawn by Champion and Seth (1968) [22]. Out of 20 transects, 5 transects represents Moist Bamboo Brakes (MBB) dominated by Bambusa tulda, 6 transects from Moist Deciduous Sal (MDS) patch dominated by Shorea robusta, 5 transects represents Moist Mixed Deciduous (MMD) patch dominated by Schima wallichii and 4 transects from Semi Evergreen Dipterocarpus (SED) patches dominated by Dipterocarpus turbinatus. All woody individuals at $\geq 10 \mathrm{~cm}$ girth at breast height (gbh), at $1.3 \mathrm{~m}$ height were measured in $10 \mathrm{~m}$ wide and $500 \mathrm{~m}$ length transects. Thus, each line transect represented an area of 0.5 ha $(10 \times 500 \mathrm{~m})$ and encompassed $5(10 \times 100 \mathrm{~m})$ contiguous sub-plots. Specimens were identified with the help of The Flora of Tripura State [24]. The reference herbarium was deposited in herbarium of Botany Department; Tripura University. Information about individual species, their status including their herbarium voucher number recorded from the study site is available in a separate publication [23].

\subsection{Data Analysis}

Field data were quantitatively analysed on per hectare basis for density and basal area [25]. For estimation of woody Above Ground Biomass (AGB), regression model was used proposed by Brown et al. (1989) [26] due to relatively similar climatic condition of the study area (rainfall $150-400 \mathrm{~cm}$ range per year): AGB per woody species in $\mathrm{kg}(\mathrm{Y})=$ $42.69-12.800(\mathrm{dbh})+1.242\left(\mathrm{dbh}^{2}\right)$ was and presented into S I unit (AGB Mg ha $\left.{ }^{-1}\right)$. Where, DBH ranges between $5-148 \mathrm{~cm}$, number of sampled tree was 170 and regression coefficient $\left(\mathrm{R}^{2}\right)=0.84$ [26]. Moist deciduous forest frequently dominated several bamboo species. Since, present study area was found to be dominate by Bambusa tulda; we used separate equation for biomass estimation of bamboo species [27], $\mathrm{W}=\mathrm{a} \mathrm{dbh}^{\mathrm{b}}$. Where, $\mathrm{W}=$ weight of bamboo culm in $\mathrm{kg}, \mathrm{dbh}=$ diameter at breast height, allometric values for $a=0.141$ and $b=2.48$ with regression coefficient $\left(R^{2}\right)=0.973$ [27]. The estimation of Cstocks ( $\mathrm{C} \mathrm{Mg} \mathrm{ha}{ }^{-1}$ ) was calculated as $50 \%$ of the total biomass; since, $\mathrm{C}$ content in plant tissue is approximately half of the dry weight of aboveground live bio- 
mass [4] [6]. The significance of differences in forest structural variables among the patches was statistically tested using one-way analysis of variance (ANOVA) and Tukey's test.

To compare the size-class distributions of biomass storage in each forest patches, we plotted AGB and C Mg ha ${ }^{-1}$ along ten gbh classes (>10, 10.1 - 20, $20.1-30,30.1-40$, $40.1-50,50.1-60,60.1-70,70.1-80,80.1-90$ and $>90 \mathrm{~cm})$. The relationship between AGB Mg ha ${ }^{-1}$ (y) and density ha ${ }^{-1}(\mathrm{x})$ along teng bh classes in four different forest patches were examined and compared by linear curve fitting. The statistical analysis was performed by PAST version 1.89 [28].

\section{Results and Discussion}

\subsection{Woody Vegetation Structure}

Stem density was recorded highest for MBB $\left(1088.4 \pm 96.15 \mathrm{ha}^{-1}\right)$ and lowest in case of SED $\left(701 \pm 45.79 \mathrm{ha}^{-1}\right)$. However, density of stems was found varied significantly ( $\mathrm{F}=$ $4.20, \mathrm{df}=3.19 ; \mathrm{p}=0.02)$ within the forest patches. Basal area at the study sites ranged between $8.91 \pm 1.39 \mathrm{~m}^{2} \mathrm{ha}^{-1}$ (MMD)to $33.69 \pm 8.76 \mathrm{~m}^{2} \mathrm{ha}^{-1}$ (SED), followed by $9.17 \pm$ $1.24 \mathrm{~m}^{2} \mathrm{ha}^{-1}$ in MBB and $9.05 \pm 1.60 \mathrm{~m}^{2} \mathrm{ha}^{-1}$ in MDS. Basal area also significantly varied $(\mathrm{F}=10.04, \mathrm{df}=3.19 ; \mathrm{p}<0.001)$ among the patches. Mean stem dbh was significantly high in SED $(50.56 \pm 2.77 \mathrm{~cm})$ than other patches $(\mathrm{F}=25.88, \mathrm{df}=3.19 ; \mathrm{p}<0.001)$. Even, mean canopy height $(\mathrm{m})$ was also recorded high in SED $(9.28 \pm 0.97 \mathrm{~m})$ and found significantly differed among the forest patches $(\mathrm{F}=12.71 \mathrm{df}=3.19 ; \mathrm{p}<0.001)$ (Table 1$)$.

Highest stem density in $\mathrm{MBB}$ might be due to high abundance of Bambusa tulda $\left(\right.$ density $\mathrm{ha}^{-1}$ ); which is locally adaptive and ecologically dominated species, facilitated

Table 1. Woody species structural variables (Mean \pm SE) along forest patches in TWS. Variations are analyzed by ANOVA (degree of freedom 3, 19).

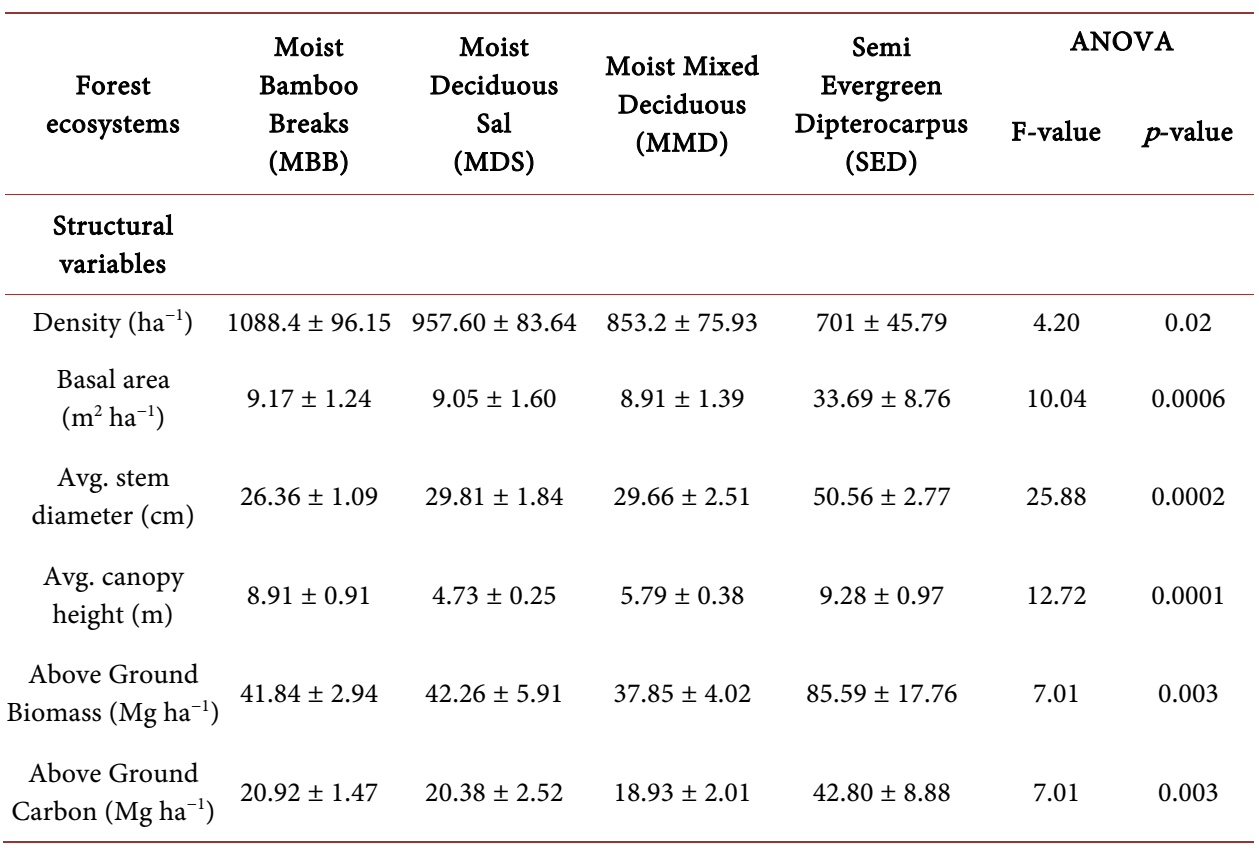


with high regeneration abilities and greater growth rate [29]. Even, high growth trait of bamboo can fix atmospheric $\mathrm{C}$ faster than similar dbh sized of a tree. In fact, Bambusa tulda have the potentiality to shift the present forest under bamboo controlled retrogression stage. Usually, there is a high density of stems with low dbh in early and intermediate stages (e.g. MMD and MBB patches), and as dbh increases with successional trend, stem density decreases in late stage (SED patch). Negi et al. (2003) [30] observed that the tree types have maximum $\mathrm{C}$ stored in the order conifers $>$ deciduous $>$ evergreen $>$ bamboos. Instead of low stem density in SED patch $\left(701 \pm 45.79 \mathrm{ha}^{-1}\right)$, basal area was significantly high $\left(33.69 \pm 8.76 \mathrm{~m}^{2} \mathrm{ha}^{-1}\right)$ due to presence of voluminous Dipterocarpus turbinatus as the representative of late successional stage. Nevertheless, forest structure changed along the successional gradient according to the general pattern of secondary succession with a gradual increase in height and basal area as described for tropical forests. In addition, Shorea robusta and Dipterocarpus turbinatus locally possess good natural regeneration trait and fast growing ability [31]. Therefore, these species came out as significant $\mathrm{C}$ sequester in this region and long term monitoring of $\mathrm{C}$ dynamics in those forests are possible through timescale observation on these two key dominated species. We also predicted that, significant differences in species composition and dominant trends may influence the biomass and $\mathrm{C}$ stock in each forest patch through control over water availability, litter and debris deposition, composition and quantity of root exudates and the distribution of $\mathrm{C}$ in the soil profile.

\subsection{Status of Biomass and C Stocks along the Forest Patches}

The value of AGB in the whole study area, ranged between $20.86 \mathrm{Mg} \mathrm{ha}^{-1}$ (MDS) to 126.37 $\mathrm{Mg} \mathrm{ha}^{-1}$ (SED). However, mean AGB was significantly greater $(\mathrm{F}=7.01$, $\mathrm{df}=$ 3.19; $\mathrm{p}<0.01)$ in SED $\left(85.59 \pm 17.76 \mathrm{Mg} \mathrm{ha}^{-1}\right)$ than recorded minimum value $(37.85 \pm$ $4.02 \mathrm{Mg} \mathrm{ha}^{-1}$ ) in case of MMD. Highest contributor of AGC stock was SED patch (35.13 \pm $\left.8.88 \mathrm{Mg} \mathrm{ha}^{-1}\right)$ followed by MBB $\left(22.08 \pm 2.60 \mathrm{Mg} \mathrm{ha}^{-1}\right)$, MDS $\left(19.11 \pm 2.39 \mathrm{Mg} \mathrm{ha}^{-1}\right)$ and MMD (18.92 $\left.\pm 2.01 \mathrm{Mg} \mathrm{ha}^{-1}\right)$, which also found significantly varied among the different patches $(\mathrm{F}=7.01, \mathrm{df}=3.19 ; \mathrm{p}<0.01)$ (Table 2). In MBB patch, Bambusa tulda contributed about $35.5 \%$ (14.46 $\mathrm{Mg} \mathrm{ha}^{-1}$ ) of total biomass. Other dominant tree shared less than $10 \%$ of total biomass i.e. Schima wallichii $\left(9.21 \%\right.$ or $\left.3.86 \mathrm{Mg} \mathrm{ha}^{-1}\right)$; Terminalia bellirica (6.55\% or $2.72 \mathrm{Mg} \mathrm{ha}^{-1}$ ); Microcos peniculata (4\% or $1.68 \mathrm{Mg} \mathrm{ha}^{-1}$ ) and Lannea coromandellica (2.62\% or $1.10 \mathrm{Mg} \mathrm{ha}^{-1}$ ). In MDS patch, Shorea robusta was the highest contributor and shared about $56.33 \%\left(23.81 \mathrm{Mg} \mathrm{ha}^{-1}\right)$ of total biomass followed by Dipterocarpus turbunatus $6.09 \%\left(2.58 \mathrm{Mg} \mathrm{ha}^{-1}\right)$, Schima wallichii $3.33 \%\left(1.41 \% \mathrm{Mg} \mathrm{ha}^{-1}\right)$, Terminalia bellirica $3.13 \%\left(1.33 \mathrm{Mg} \mathrm{ha}^{-1}\right)$ and Microcos peniculata $2.14 \%\left(0.91 \mathrm{Mg} \mathrm{ha}^{-1}\right)$. Among the present studied forest patches, most common dominant species was Schima wallichii and it contributed about $8.1 \%\left(16.63 \mathrm{Mg} \mathrm{ha}^{-1}\right)$ of the total biomass of the study area. Overall, the highest contributor was Dipterocarpus turbinatus, it shared about $22.34 \%\left(46.38 \mathrm{Mg} \mathrm{ha}^{-1}\right.$ ) of total biomass (Table 2). In the present estimation of total biomass, $70 \%$ was stocked at $<30 \mathrm{~cm}$ dbh class; which indicated sufficient amount of young stems or maximum number of trees could not attained full maturity in those 
Table 2. Above ground biomass and carbon contribution by top five dominant species along forest patches in TWS.

\begin{tabular}{ccccc}
\hline \multirow{2}{*}{ Species } & \multicolumn{2}{c}{ Above Ground Biomass/Above Ground Carbon $\left(\mathrm{Mg} \mathrm{h}^{-1}\right)$} \\
\cline { 2 - 5 } & MBB & MDS & MMD & SED \\
\hline Aporosa octandra & - & - & $1.45 / 0.72$ & - \\
Bambusa tulda & $14.46 / 7.23$ & - & - & - \\
Careya arborea & - & - & $1.29 / 0.65$ & - \\
Castanopsis indica & - & - & - & $2.06 / 1.03$ \\
Dipterocarpus turbinatus & - & $2.58 / 1.29$ & - & $43.80 / 21.90$ \\
Ficus religiosa & - & - & - & $2.09 / 1.04$ \\
Holarrhena pubescens & - & - & $1.10 / 0.55$ & - \\
Lannea coromandelica & $1.10 / 0.55$ & - & - & - \\
Microcos paniculata & $1.68 / 0.84$ & $0.91 / 0.45$ & - & $2.55 / 1.27$ \\
Schima wallichii & $3.86 / 1.93$ & $1.41 / 0.71$ & $1.88 / 0.94$ & $9.49 / 4.74$ \\
Shorea robusta & - & $23.81 / 11.90$ & - & - \\
Terminalia bellirica & $2.72 / 1.36$ & $1.33 / 0.66$ & $2.24 / 1.12$ & - \\
Sum of 5 most dominant & $23.81 / 11.90$ & $30.03 / 15.01$ & $7.96 / 3.98$ & $59.98 / 29.99$ \\
Rest other species & $17.67 / 8.83$ & $12.23 / 6.12$ & $29.89 / 14.95$ & $25.61 / 12.80$ \\
Total & $41.48 / 20.74$ & $42.26 / 21.13$ & $37.85 / 18.93$ & $85.59 / 42.80$ \\
\hline
\end{tabular}

forest patches, possibly these forest patches were recovering from significant historic disturbances. Being as early and intermediated stages MMD and MBB patches (37.85 and $\left.41.84 \mathrm{Mg} \mathrm{ha}^{-1}\right)$ recover much biomass compared to MDS patch $(42.26 \pm 5.91 \mathrm{Mg}$ $\left.\mathrm{ha}^{-1}\right)$. This may due to the changes in forest composition and structure during succession, occurred at very different rates; and biomass generally recovers more rapidly than species richness [8] [11] [12]. About $40 \%$ tree species contributed $>70 \%$ of total biomass in dry deciduous forest [26] [27]. In the present moist deciduous forest patches, five most dominant species contributed $57.41 \%$ of biomass in $\mathrm{MBB}, 70.06 \%$ in MDS, $21.02 \%$ in MMD and $70.08 \%$ in SED. Out of 5 most dominated species in all forest patches, the top dominant species contributed $34.85 \%$ biomass (Bambusa tulda) in MBB, Shorea robusta had 56.34\% biomass in MDS, Terminalia bellirica had 5.92\% in MMD and Dipterocarpus turbinatus contributed 51.18\% biomass in SED (Table 2). Both SED and MSD forests were came out as more mature or late successional phase than other patches and might preserve much more $\mathrm{C}$ and also responsible for greater $\mathrm{C}$ management. Further, AGB recorded in the present study ranged from $20.86 \mathrm{Mg} \mathrm{ha}^{-1}$ to $126.37 \mathrm{Mg} \mathrm{ha}^{-1}$ also fall within the range of the earlier study from the area [15]-[17], which was found less than AGB value of Central Himalaya (171.9 - 380.3 $\mathrm{Mg} \mathrm{ha}^{-1}$ ) [32], Western Ghats (468 - 607.7 $\mathrm{Mg} \mathrm{ha}^{-1}$ ) [33] and in Eastern Ghats (15.61 - 597.13 $\mathrm{Mg} \mathrm{ha}^{-1}$ ) [34]. Present AGB value was found close to other reported value of biomass in northeast India viz. Meghalaya, Assam and Manipur [10]-[12].

Estimation of live tree biomass is very crucial for an ecosystem, especially to understand overall ecosystem health and services including the hydrological cycle, soil ero- 
sion, nutrient cycling and dynamics of terrestrial C [3] [5] [6]. Although, our biomass and $\mathrm{C}$ stock means were statistically different, which suggested there was considerable variation in stand structure across the forest patches. The biomass contrast of five top most dominant trees was consistent with diversity and structural complexity. For instance, basal area, density of voluminous trees and diameter were found greater in late successional forest patch (SED) than the patches at early stages, and thereby represented higher quantity of biomass and C stocks (Table 1). Results also suggest that key dominant trees make a proportionately greater contribution to total biomass as stands undergo late-successional development [4] [5] [20] [21]. Our rationale was that local ecological factors (patch size, isolation, species composition, soils, productivity, and disturbance regimes) were accounted for variability in biomass $\mathrm{C}$ stock levels in those forest patches. And, succession has the potential influences to biomass development and $\mathrm{C}$ cycling in those forest patches.

\subsection{Distribution of Biomass and C Storage along the Age Classes}

Mean maximum AGC stock was recorded from $42.80 \mathrm{Mg} \mathrm{ha}^{-1}$ (SED) to18.93 $\mathrm{Mg} \mathrm{ha}^{-1}$ (MMD). The value is quite comparable with other previous estimates of biomass in different forest areas of Tripura. In India, the estimated Forest phytomass carbon density pool for the recent period are mostly in the range of $50-68 \mathrm{Mg} \mathrm{ha}^{-1}$. Tripura was having phytomass $\mathrm{C}$ density between $0-25 \mathrm{Mg} \mathrm{ha}^{-1}$ in 1988 [15] [16]. The cumulative net "C" flux from Indian Forests during 1888-1996, due to land use change (deforestation, afforestation and phytomass degradation) was estimated at 4.54 PgC. Using Biomass expansion factor total estimated biomass of Tripura was about $40 \mathrm{Mt}$. In Tripura average biomass density ranged from 66.7 to $83.6 \mathrm{Mg} \mathrm{ha}^{-1}$ for open forest and dense forest respectively [16] [17]. While, stocks of $C$ was substantially declined in larger dbh classes; except in case of SED patch, most stock of AGC was restricted in smaller dbh classes $(<30 \mathrm{~cm})$ (Figure 2). Comparison of allometric relationships between total AGB and density distribution in different dbh classes in four tropical moist deciduous forest patches implied that there were significant differences among the AGB distribution (Figure 3). Overall, $69.38 \%$ (35.73 $\mathrm{Mg} \mathrm{ha}^{-1}$ ) of total biomass was concentrated in $<30$ $\mathrm{cm}$ dbh class and $23 \%$ at $>70 \mathrm{~cm}$ dbh class $\left(12.08 \mathrm{Mg} \mathrm{ha}^{-1}\right)$. The intermediated $\mathrm{dbh}$ classes between $>30$ to $<70 \mathrm{~cm}$ contributed only $7 \%$ of biomass $\left(3.69 \mathrm{Mg} \mathrm{ha}^{-1}\right)$. However in $\mathrm{MBB}, 90 \%$ ( $37.55 \mathrm{Mg} \mathrm{ha}^{-1}$ ) of biomass was represented by $<40 \mathrm{~cm}$ girth class, which indicated that the higher proportion of AGB was contributed by lower $\mathrm{dbh}$ classes, particularly in the form of dominated bamboo culms. Biomass distribution in $10 \mathrm{dbh}$ classes was significantly varied $(\mathrm{F}=74.13, \mathrm{df}=1.9 ; \mathrm{p}<0.001)$, which showed relatively highest coefficient for allometric relationships between density and AGB in different dbh classes (equation: $\mathrm{Y}=0.56 \mathrm{X}-0.23, \mathrm{R}^{2}=0.90$; Figure $3 \mathrm{MBB}$ ). In MDS patch, about $90 \%$ (36.62 $\mathrm{Mg} \mathrm{ha}^{-1}$ ) of AGB was concentrated in $<20 \mathrm{~cm}$ dbh class and $8 \%$ (3.35 $\mathrm{Mg} \mathrm{ha}^{-1}$ ) between $<30$ to $<60 \mathrm{~cm}$ dbh class; but only $1.45 \%\left(0.59 \mathrm{Mg} \mathrm{ha}^{-1}\right)$ of ABG represented by higher dbh class $(>90 \mathrm{~cm})$. Analysis showed that the allometric equation of total AGB and density distribution highly correlated $\left(\mathrm{Y}=0.56 \mathrm{X}-0.20, \mathrm{R}^{2}=0.81\right.$; 
Figure $3 \mathrm{MDS})$. AGB distribution was significantly higher $(\mathrm{F}=34.59$, $\mathrm{df}=1.9 ; \mathrm{p}<$ 0.001) among the lower dbh classes which indicated that forest is either immature or recovering its maturity from historic disturbances. About 75\% (28.28 $\mathrm{Mg} \mathrm{ha}^{-1}$ ) of AGB was contributed by $<20 \mathrm{~cm}$ dbh and about $90 \%$ of biomass $\left(33.22 \mathrm{Mg} \mathrm{ha}^{-1}\right)$ by $<30 \mathrm{~cm}$ dbh class in MMD patch. In addition, analysis showed low correlation for the allometric equation $\left(\mathrm{Y}=0.49 \mathrm{X}-0.08, \mathrm{R}^{2}=0.76\right.$; Figure $\left.3 \mathrm{MMD}\right)$ of total $\mathrm{AGB}$ in $\mathrm{MMD}$ and AGB distribution was significantly less in the higher dbh classes $(\mathrm{F}=25.25, \mathrm{df}=1.9 ; \mathrm{p}<$ $0.001)$. Whether in case of SED patch, only $51 \%\left(44.33 \mathrm{Mg} \mathrm{ha}^{-1}\right)$ of AGB was shared by $<60 \mathrm{~cm}$ dbh class and 39\% (33.55 $\left.\mathrm{Mg} \mathrm{ha}^{-1}\right)$ contributed by due to $>90 \mathrm{~cm} \mathrm{dbh}$; whereas total AGB as a function of density distribution in dbh classes showed low correlation $(\mathrm{Y}=$ $0.35 \mathrm{X}-0.31, \mathrm{R}^{2}=0.48$; Figure $3 \mathrm{SED}$ ), significantly high biomass storage among the larger dbh classes $(\mathrm{F}=7.41, \mathrm{df}=1.9 ; \mathrm{p}<0.05)$. Among the tree species, Dipterocarpus turbinatus (43.80 $\mathrm{Mg} \mathrm{ha}^{-1}$ ) accounted highest AGB in SED patch followed by Shorea robusta (23.81 $\mathrm{Mg} \mathrm{ha}^{-1}$ ) for MDS patch, Bambusa tulda (14.46 $\mathrm{Mg} \mathrm{ha}^{-1}$ ) for $\mathrm{MBB}$ patch and Terminalia bellirica (2.24 $\mathrm{Mg} \mathrm{ha}^{-1}$ ) for MMD patch (Table 2).

Likewise, Day et al. (2014) also reported high variability in biomass distribution, but in general more diverse forest tends to be accumulating more biomass [35]. In spite of having highest species richness, MMD had lowest value of biomass (37.85 \pm 4.02$)$; even, there was also relatively low coefficient $\left(\mathrm{R}^{2}=0.76 ; \mathrm{p}<0.01\right)$ for allometric relationships between density distribution and AGB (Figure 3 MMD). Similarly tree density was

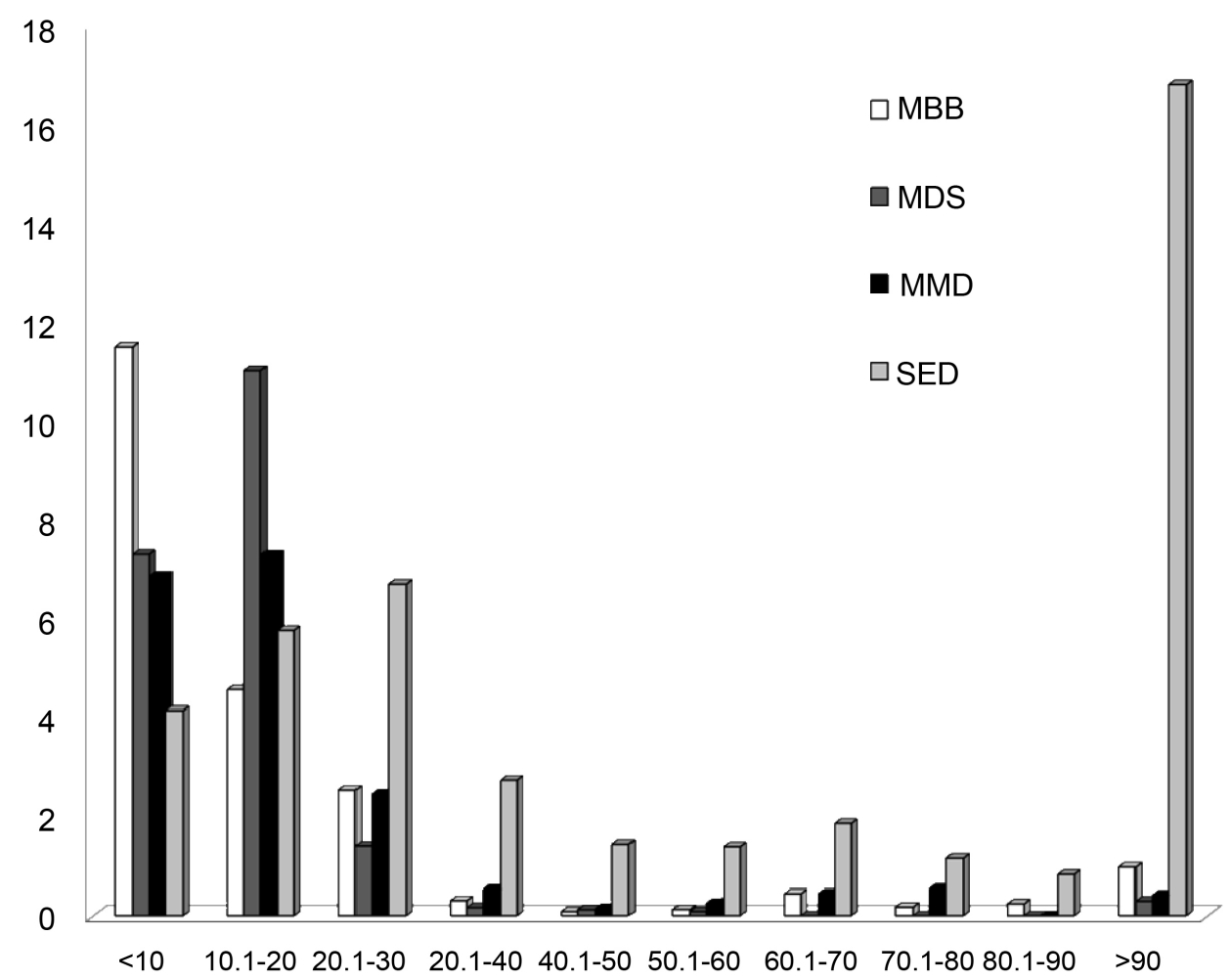

Figure 2. Distribution of Above Ground Carbon $\mathrm{Mg} \mathrm{ha}^{-1}$ along different diameter classes in four major forest types in TWS. 
highest for MBB $(1088.4 \pm 96.15)$, but it had lower value of biomass $(41.84 \pm 2.94)$ showed relatively highest coefficient value $\left(R^{2}=0.90 ; p<0.001\right)$ for allometric relationships between density distribution and AGB (Figure $3 \mathrm{MBB}$ ). Inverse to that, SED
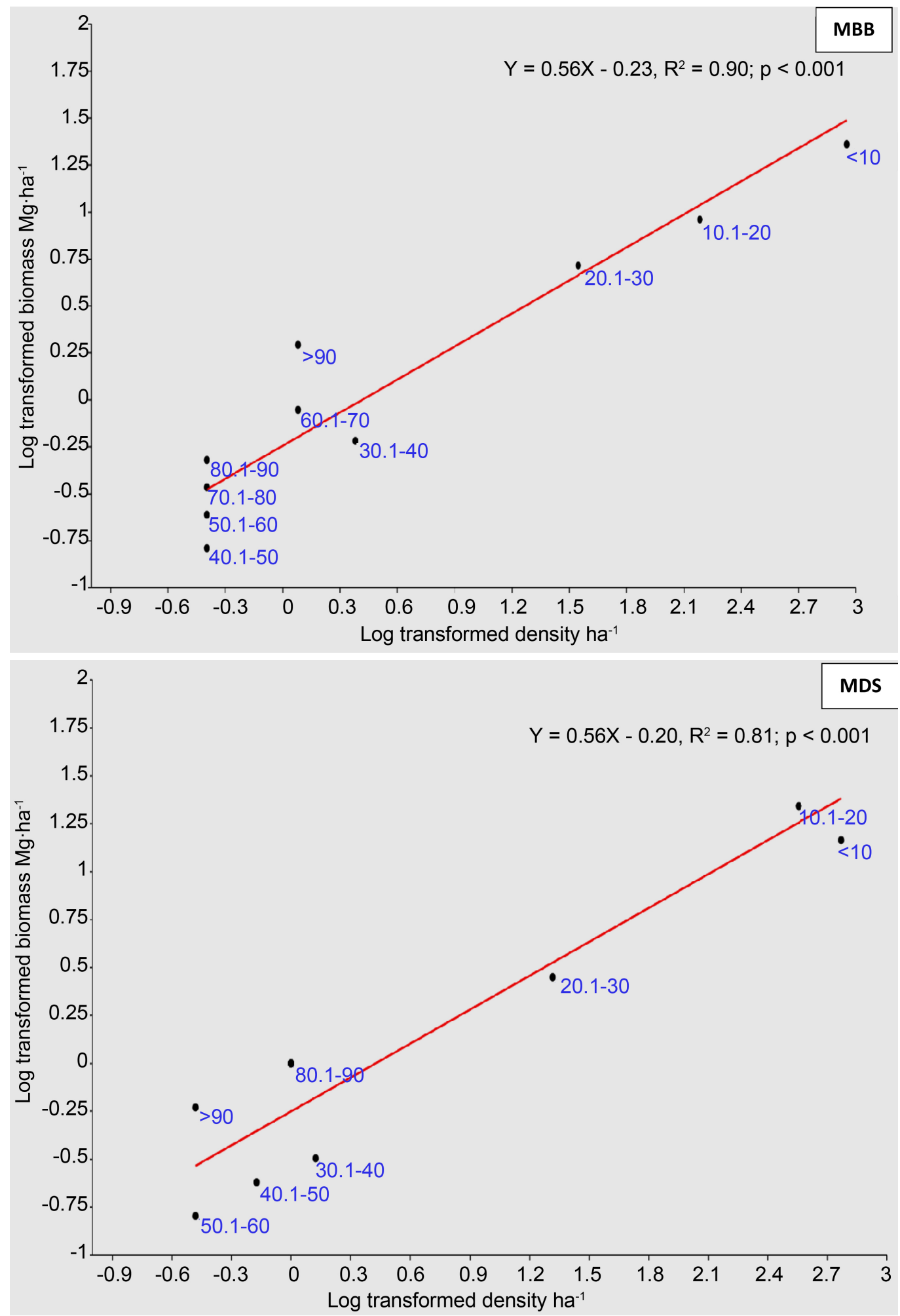

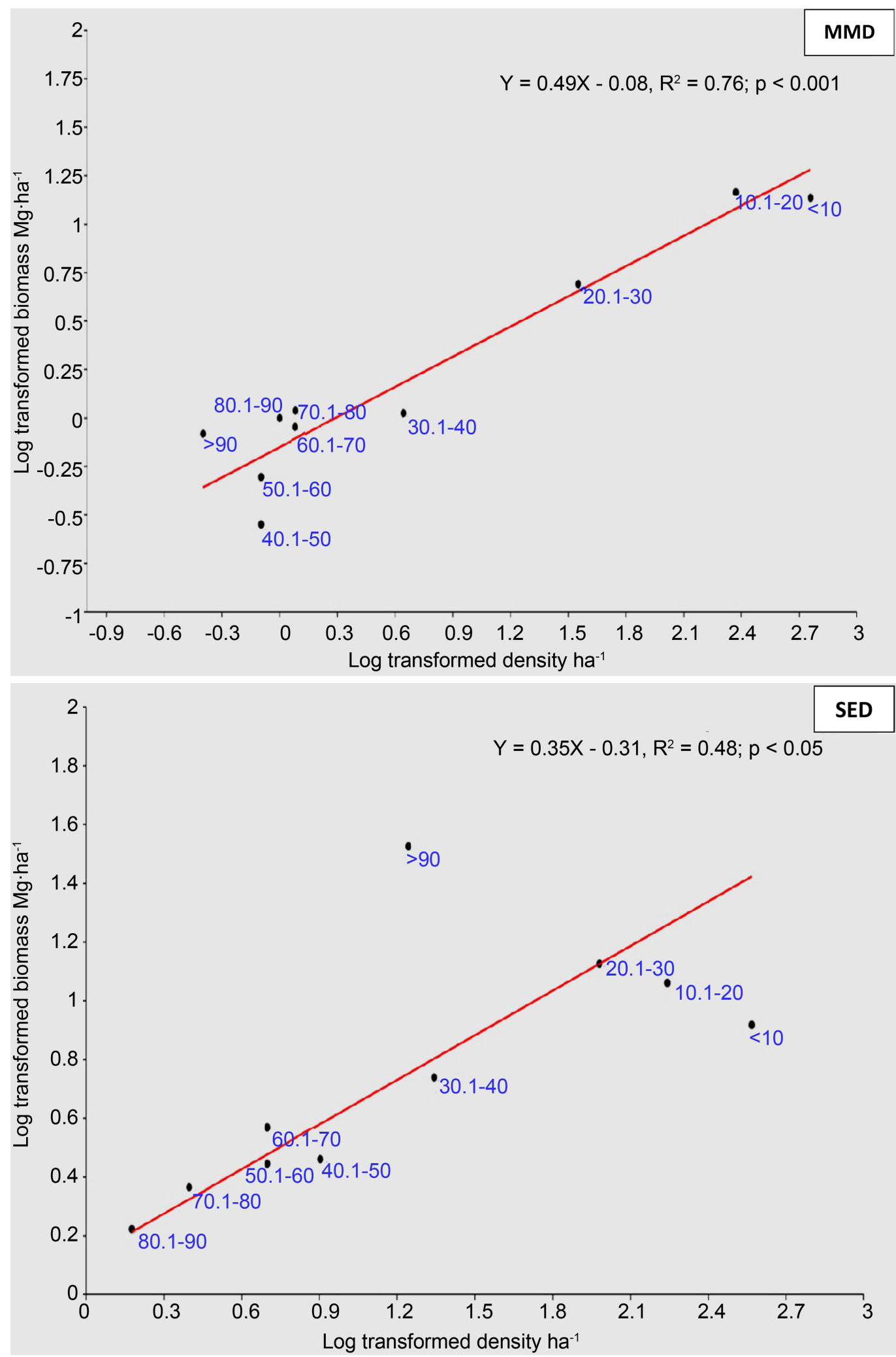

Figure 3. Relationship between log transformed AGB and density ha ${ }^{-1}$ in different dbh classes along major forest patches (MBB, MDS, MMD and SED) in Trishna Wildlife Sanctuary of Tripura, Northeast India. 
had highest amount of biomass stock ( $85.59 \pm 17.76)$ but was relatively lowest correlation coefficient $\left(\mathrm{R}^{2}=0.48 ; \mathrm{p}<0.05\right)$ for equation relationships (Figure $3 \mathrm{SED}$ ); which may due to low density and irregular distribution of trees along the dbh classes. This may further be able to explain by the fact that differences in tree composition and dominance of the species along the patches, and more importantly this may related to the forest successional age [10] [20] [21]. On the basis of biomass stocked in all dbh classes, SED patch found different from rest other three types; where trees in higher dbh class $>90 \mathrm{~cm}$ stocked maximum biomass (40\%) and might represented that this forest community has comparatively reached to its maximum potential in terms of sequestration of $\mathrm{CO}_{2}$. Surprisingly, Bambusa tulda in MBB patch contributed about $35 \%$ of biomass, this shows that bamboo patch could capture considerable amount of $\mathrm{CO}_{2}$ within very early stage. $\mathrm{C}$ pool in the above ground biomass of village bamboo in Assam increased from $21.69 \mathrm{Mg} \mathrm{ha}^{-1}$ to $76.55 \mathrm{Mg} \mathrm{ha}^{-1}$ within three years [14]. The recovery of biodiversity and biomass in tropical moist deciduous forest patches provides hope that they are helping to sequester considerable amount of atmospheric $\mathrm{C}$. It is predicted that present trends will change over time when the early stages will grow into more mature layers and subsequently increase total biomass and C stock in those patches in course of secondary succession. In addition, sapling or regenerating woody stems density was high in MMD and MBB patches; which suggested that these forest patches can provide important ecosystem services as $\mathrm{C}$ sequestration. Since the regenerating stage of most woody species can sequester considerable amount of $\mathrm{CO}_{2}$ by reducing it into biomass [18]. Our result also supporting the potentiality of fragmented village bamboo patches for quick $\mathrm{C}$ sequestration; and, this is due to bamboo rapid growth rate, easy multiplication ability and high biomass production. In fact, $\mathrm{C}$ assimilation in bamboo plantation is $16 \%$ - $20 \%$ more compared to other planted tree species i.e. Dalbergia sissoo $(11.11 \%)$, Terminalia arjuna (12.07\%) and natural forest of Shorea robusta (3.34\%) [14].

\section{Conclusion}

In this present study, depending on heterogeneity in forest patches the amount of biomass and $\mathrm{C}$ stock determined and found differed significantly. Species specific biomass structure and its distribution along different dbh classes are very important to know $\mathrm{C}$ dynamics and its sequestration processes. Besides $\mathrm{AGB}$, it would be more crucial if $\mathrm{C}$ accumulation rates in below ground biomass, dead material, and soil along the landscapes specifically could be estimated. Even, studies also required to understand the key processes of biomass and $\mathrm{C}$ accumulation through time scale investigation in those forest patches. There are wide variations in terms of biomass distribution and $\mathrm{C}$ storage in the patch area, which suggested that present forest patches have huge potentiality as $\mathrm{C}$ sequestration and stocked it in the form of biomass. Climate change mitigations by restoring $\mathrm{CO}_{2}$ through different local forest patches have great advantages like conservation of other species and other ecological services. Hence, it is possible that small forest patches or fragmented forest landscapes may claim enough incentive by demanding fund against management of local landscapes for restoration of $\mathrm{CO}_{2}$ and conserva- 
tion of biodiversity. Present quantitative structural attributes of small forest patches will be vital in future to understand $\mathrm{C}$ dynamics in small forest patches including the role of dominant community, niche attributes, successional trend, effects of edge and on-going disturbances on the distribution and population of threatened species.

\section{References}

[1] Phillips, O.L., Malhi, Y., Higuchi, N., Laurance, W.F., Nunez, P.V., Vasquez, R.M., Laurance, S.G., Ferreira, L.V., Stern, M., Brown, S. and Grace, J. (1998) Changes in the Carbon Balance of Tropical Forest: Evidence from Long-Term Plots. Science, 282, 439-442. http://dx.doi.org/10.1126/science.282.5388.439

[2] Pan, Y., Birdsey, R.A., Fang, J., Houghton, R., Kauppi, P.E., Kurz, W.A. and Philips, O.L (2011) A Large and Persistent Carbon Sink in the World's Forests. Science, 333, 988-993. http://dx.doi.org/10.1126/science.1201609

[3] Houghton, R.A. (2005) Aboveground Forest Biomass and the Global Carbon Balance. Global Change Biology, 11, 945-958. http://dx.doi.org/10.1111/j.1365-2486.2005.00955.x

[4] Brown, S., Hall, C.A.S., Knabe, W., Raich, J., Trexler, M.C. and Woomer, P. (1993) Tropical Forests: Their Past, Present and Potential Future Roles in the World's Carbon Budget. Water Air Soil Pollution, 70, 71-94. http://dx.doi.org/10.1007/BF01104989

[5] Dixon, R.K., Brown, S.A., Houghton, R.A., Solomon, A.M., Trexler, M.C. and Wisniewski, J. (1994) Carbon Pools and Flux of Global Forest Ecosystems. Science, 263, 185-190. http://dx.doi.org/10.1126/science.263.5144.185

[6] Malhi, Y. and Grace, J. (2000) Tropical Forests and Atmospheric Carbon Dioxide. Trends in Ecology and Evaluation, 15, 332-337. http://dx.doi.org/10.1016/S0169-5347(00)01906-6

[7] Sodhi, N.S., Koh, L.P., Brook, B.W. and Ng, P.K.L. (2004) Southeast Asian Biodiversity: An Impending Disaster. Trends in Ecology and Evaluation, 19, 654-660. http://dx.doi.org/10.1016/j.tree.2004.09.006

[8] Ramachandra, T.V. and Shwetmala (2012) Decentralised Carbon Footprint Analysis for Opting Climate Change Mitigation Strategies in India. Renewable and Sustainable Energy Reviews, 16, 5820-5833. http://dx.doi.org/10.1016/j.rser.2012.05.035

[9] MoEF (2009) India's Fourth National Report to the Convention on Biological Diversity. New Delhi: Ministry of Environment and Forests, Government of India.

[10] Baishya, R., Barik, S.K. and Upadhaya, K. (2009) Distribution Pattern of Aboveground Biomass in Natural and Plantation Forests of Humid Tropics in Northeast India. Tropical Ecology, 50, 295-304.

[11] Borah, N., Nath, A.J. and Das, A.K. (2013) Aboveground Biomass and Carbon Stocks of Tree Species in Tropical Forests of Cachar District, Assam, Northeast India. International Journal of Ecology Environmental Science, 39, 97-106.

[12] Thokchom, A. and Yadava, P.S. (2013) Biomass and Carbon Stock Assessment in the Sub-Tropical Forests of Manipur, North-East India. International Journal of Ecology Environmental Science, 39, 107-113.

[13] Nath, A.J. and Das, A.K. (2011) Carbon Storage and Sequestration in Bamboo-Based Smallholder Homegardens of Barak Valley, Assam. Current Science, 100, 229-233.

[14] Rao, R.R. (1994) Biodiversity in India: Floristic Aspects. Bishen Singh Mahendra Pal Singh, Dehra Dun.

[15] Chhabra, A., Palria, S. and Dadhwal, V.K. (2002) Growing Stock-Based Forest Biomass Estimate for India. Biomass and Bioenergy, 22, 187-194. 
http://dx.doi.org/10.1016/S0961-9534(01)00068-X

[16] Chhabra, A. and Dadhwal, V.K. (2004) Assessment of Major Pools and Fluxes of Carbon in Indian Forests. Climatic Change, 64, 341-360. http://dx.doi.org/10.1023/B:CLIM.0000025740.50082.e7

[17] FSI (2010) State of the Forest Report 2010. Forest Survey of India, Ministry of Environment and Forest, Goverment of India, Dehradun.

[18] IPCC (1996) Climate Change Impacts, Adaptations and Mitigation of Climate: Scientific Technical Analyses. In: Contribution of II to the Second Assessment Report of the Intergovernmental Panel on Climate Change, Cambridge University Press, Cambridge.

[19] Ramachandran, A., Jayakumar, S., Haroon, R.M., Bhaskaran, A. and Arockiasamy, D.I. (2007) Carbon Sequestration: Estimation of Carbon Stock in Natural Forests Using Geospatial Technology in the Eastern Ghats of Tamil Nadu, India. Current Science, 92, 323331.

[20] Sharma, C.M., Baduni, N.P., Gairola, S., Ghildiyal, S.K. and Suyal, S. (2010) Tree Diversity and Carbon Stocks of Some Major Forest Types of Garhwal Himalaya, India. Forest Ecology and Management, 260, 2170-2179. http://dx.doi.org/10.1016/j.foreco.2010.09.014

[21] Lasky, J.R., Uriarte, M., Boukili, V.K., Erickson, D.L., John Kress, W. and Chazdon, R.L. (2014) The Relationship between Tree Biodiversity and Biomass Dynamics Changes with Tropical Forest Succession. Ecology Letters, 17, 1158-1167. http://dx.doi.org/10.1111/ele.12322

[22] Champion, H.G. and Seth, S.K. (1968) A Revised Forest Types of India. Manager of Publications, Government of India, Delhi.

[23] Majumdar, K. and Datta, B.K. (2014) A Quantitative Checklist of Woody Angiosperm Diversity, Population Structure and Habitat Grouping in Trishna Wildlife Sanctuary of Tripura, Northeast India. Check List, 10, 976-996. http://dx.doi.org/10.15560/10.5.976

[24] Deb, D.B. (1981-1983) The Flora of Tripura State. Vols. 1-2, Today and Tomorrow's Printers and Publishers, New Delhi.

[25] Muller, D.D. and Ellenberg, H. (1974) Aims and Methods of Vegetation Ecology. John Wiley and Sons Inc, Hoboken.

[26] Brown, S., Gillespie, A. and Lugo, A.E. (1989) Biomass Estimation Methods for Tropical Forests with Applications to Forest Inventory Data. Forest Science, 35, 881-902.

[27] Maki, F., Mamoru, K., Maung, T.H. and Yazar, M. (2007) Recovery Process of Fallow Vegetation in the Traditional Karen Swidden Cultivation System in the Bago Mountain Range, Myanmar. Southeast Asian Studies, 45, 317-333.

[28] Hammer, O., Harper, D.A.T. and Ryan, P.D. (2009) PAST-Palaeontological Statistics, ver. 1.89. University of Oslo, Oslo.

[29] Majumdar, K., Das, P. and Datta, B.K. (2012) Seed Germination and Growth of Bambusa tulda Roxb. in Tree Cavity : An Accidental Phenomenon. Nebio, 3, 128-130.

[30] Negi, J.D.S., Manhas, R.K. and Chauhan, P.S. (2003) Carbon Stocks in Different Components of Some Tree Species of India: A New Approach for Carbon Estimation. Current Science, 85, 1528-1531.

[31] Majumdar, K., Shankar, U. and Datta, B.K. (2012) Tree Species Diversity and Stand Structure along Major Community Types in Lowland Primary and Secondary Moist Deciduous Forests in Tripura, Northeast India. Journal of Forestry Research, 23, 553-568. http://dx.doi.org/10.1007/s11676-012-0295-8 
[32] Gairola, S., Sharma, C.M., Ghildiyal, S.K. and Suyal, S. (2011) Live Tree Biomass and Carbon Variation along an Altitudinal Gradient in Moist Temperate Valley Slopes of the Garhwal Himalaya (India). Current Science, 100, 1862-1870.

[33] Swamy, H.R. (1989) Study of Organic Productivity, Nutrient Cycling and Small Watershed Hydrology in Natural Forests and in Monoculture Plantations in Chikamagalur District, Karnataka, Final Report, Sri Jagadguru Chandrashekara Bharti Memorial College, Sringeri.

[34] Mohanraj, R., Saravan, J. and Dhanakumar, S. (2011) Carbon Stock in Kolli Forests, Eastern Ghats (India) with Emphasis on Aboveground Biomass, Litters, Woody Debris and Soil. iForest, 4, 61-65. http://dx.doi.org/10.3832/ifor0568-004

[35] Day, M., Cristina, B., Sunderland, E.R. and Terry, C.H. (2014) Environmental Conservation: Relationships between Tree Species Diversity and Above-Ground Biomass in Central African Rainforests: Implications for REDD. Environmental Conservation, 41, 64-72. http://dx.doi.org/10.1017/S0376892913000295

Submit or recommend next manuscript to SCIRP and we will provide best service for you:

Accepting pre-submission inquiries through Email, Facebook, LinkedIn, Twitter, etc. A wide selection of journals (inclusive of 9 subjects, more than 200 journals)

Providing 24-hour high-quality service

User-friendly online submission system

Fair and swift peer-review system

Efficient typesetting and proofreading procedure

Display of the result of downloads and visits, as well as the number of cited articles

Maximum dissemination of your research work

Submit your manuscript at: http://papersubmission.scirp.org/

Or contact oje@scirp.org 